\title{
EFFECTS OF METFORMIN ON PARAMETERS OF OXIDATIVE DAMAGE IN THE RETINA OF RATS WITH IMPAIRED GLUCOSE TOLERANCE
}

\author{
Branka Đorđevići ${ }^{1}$ Dušan Sokolović ${ }^{1}$, Tatjana Cvetković ${ }^{1}$ \\ Tatjana Jevtović-Stoimenov ${ }^{1}$, Milena Despotović ${ }^{1}$, \\ Andrej Veljković ${ }^{1}$, Jelena Bašić ${ }^{1}$, Davor Đukić ${ }^{1}$, Nataša Stević ${ }^{1}$, \\ Aleksandra Veličkov², Jelena Milenković3 ${ }^{3}$ Sanja Milošević ${ }^{4}$
}

\begin{abstract}
Impaired glucose tolerance is a state characterized by hyperglycemia, but with the levels of blood glucose between normal and diabetic values. Diabetic retinopathy is a complication of diabetes the pathogenesis of which is associated with oxidative stress. Metformin is currently the drug of first choice in the treatment of diabetes mellitus type 2.

The objective was to determine whether there is oxidative damage to the retina in an animal model using the analysis of oxidative damage parameters, TBA reactive substances (TBARS) and advanced oxidative protein products (AOPP), and whether this damage can be mitigated by metformin tratment.

The experiment was performed on 10 weeks old Wistar rats randomized into 4 groups. Impaired glucose tolerance was induced by intraperitoneal injection of streptozotocin (STZ), administered 15 minutes after an intraperitoneal injection of nicotinamide. After 4 weeks, metformin was introduced $(100 \mathrm{mg} / \mathrm{kg}$, per os). After 2 weeks, the animals were sacrificed under deep anesthesia.

The concentrations of TBARS and AOPP in retinal homogenates were significantly higher in animals with impaired glucose tolerance compared to controls (TBARS: $4.09 \pm$ 0.39 vs. $2.98 \pm 0.26 ; p<0.001$ and AOPP: $34.49 \pm 3.21$ vs. $26.26 \pm 3.16 ; p<0.001)$. A strong positive correlation between serum glucose level and level of TBARS $(r=0.757, p$ $<0.01)$ and AOPP levels $(r=0.683, p<0.01)$ was found. Metformin did not show any significant effects on the examined parameters.

Values of the examined parameters indicate that impaired glucose tolerance causes a strong oxidative stress in the retina, which is the first step in the onset of diabetic retinopathy. Metformin therapy at a dose of $100 \mathrm{mg} / \mathrm{kg}$, showed no significant beneficial effect on the process of lipid peroxidation and oxidation of proteins in the tissues of the retina in animals with impaired glucose tolerance.
\end{abstract}

Acta Medica Medianae 2017;56(4):75-82.

Key words: diabetic retinopathy, oxidative stress, impaired glucose tolerance

${ }^{1}$ University of Niš, Faculty of Medicine, Department of Biochemistry, Niš, Serbia

'University of Niš, Faculty of Medicine, Department of Histology and Embriology, Niš, Serbia

${ }^{3}$ University of Niš, Faculty of Medicine, Department of

Pathophisiology, Niš, Serbia

${ }^{4}$ University of Niš, Faculty of Medicine, Niš, Serbia

Contact: Branka Đorđević

Bul. dr Zorana Đinđića 81, 18000 Niš, Serbia

E-mail: brankadjordjevic83@gmail.com

\section{Introduction}

Diabetes (diabetes mellitus) is nowadays one of the most common endocrine diseases with a constantly increasing number of patients worldwide. In 2014, as many as $9 \%$ of adults over the www.medfak.ni.ac.rs/amm age of eighteen years all over the world suffered from some form of diabetes (1). Diabetes is a chronic systemic metabolic disorder characterized by hyperglycemia, ie. elevated levels of blood glucose that occurs due to a lack of insulin (type 1) or inability of the body to use insulin (type 2). Chronic complications of diabetes include heart disease, stroke, diabetic retinopathy, diabetic nephropathy, damage to the blood vessels of the extremities, and many others (2).

According to the World Health Organization, as much as $90 \%$ of the total number of cases of diabetes in the world suffer from type 2 diabetes (3), which is usually preceded by a condition that is referred to as prediabetes, or impaired glucose tolerance. This condition is characterized by the values of glucose higher than normal (between 6 and $7 \mathrm{mmol} / \mathrm{L}$ glucose, or between 7.8 and 11.1 $\mathrm{mmol} / \mathrm{L}$ after 2 hours OGTT), but still lower than 
the value at which the diagnosis of diabetes is established. Impaired glucose tolerance may develop long before the onset of diabetes. In the population over 30 years the average length of pre-diabetes was 8.5 years for men and 10.3 years for women (4).

Diabetic retinopathy occurs as a complication of diabetes. It is the main reason of acquired blindness in adults (1). Diabetic retinopathy is characterized by gradual and progressive changes in the microvasculature that lead to increased permeability of blood vessels, swelling and retinal ischemia (5). In order to compensate for ischemia, production of vasoprliferative factors that stimulate angiogenesis retina increases, leading to the creation of new, fragile blood vessels, bleeding and retinal detachment (5). The disease develops slowly and usually without symptoms, which emphasizes the importance of early detection and prevention in prevention of vision loss.

Oxidative stress plays an important role in the pathogenesis and development of various complications in diabetes $(6,7)$, and the retina is particularly susceptible to oxidative stress due to the high demand for energy and exposure to UV radiation (8).

Oxidative stress is defined as an imbalance between the production of reactive oxygen species (ROS) and the capacity of antioxidant defense systems to neutralize those molecules. Oxygen free radicals are continuously produced in all cells in order to support the proper cell function (9). Physiologically ROS are produced during normal oxidative metabolism are eliminated by antioxidant defense system (9). Pathological conditions can arise due to an increase in production of ROS from different endogenous or exogenous sources, and/or due to their inefficient removal.

The consequences of chronic oxidative stress include damage to biological macromolecules, such as DNA, lipids, proteins, carbohydrates and disturbances in cellular homeostasis (6).

Thiobarbiturate reacting substances (TBARS) are the end products of lipid peroxidation. Malondialdehyde (MDA) is one of the final products of peroxidation of polyunsaturated fatty acids and oxidative stress parameter which indicates the intensity of lipid peroxidation (10). Advanced oxidation protein products (AOPP) are used as a marker of oxidative damage to proteins (10). Retina is characterized by a high content of polyunsaturated fatty acids which makes it particularly vulnerable to the process of lipid peroxidation (5). Furthermore, oxidative damage of proteins in the retina can lead to significant disturbances in the function of this tissue, since it requires a large number of functional, structural and regulatory proteins (tubulin, vimentin, prohibitins, ATP synthase, and others.) to sustain its proper function (11).

Metformin is a therapeutic agent which increases sensitivity to insulin and is currently used as the drug of first choice in the treatment of diabetes mellitus type 2 . There is literature data that metformin can reduce the level of oxidative stress. It has been shown that metformin reduces the concentration of oxidative stress markers in the blood of patients with type 2 diabetes (12), as well as in the kidney tissue of rats with diabetes (13). However, there is no information about whether it can offer protection against the development of diabetic retinopathy.

Since oxidative stress is an important pathogenic factor for the development of diabetic retinopathy, and impaired glucose tolerance disorder can last for approximately 10 years before the diagnosis of diabetes mellitus, our goal was to determine if there was oxidative damage to the retina in an animal model of impaired glucose tolerance by monitoring the products of lipid peroxidation (TBARS) and oxidative modification of proteins (AOPP) and whether this damage can be mitigated with metformin treatment.

\section{Material and methods}

\section{Experimental animals}

The experiment was performed on 10 weeks old Wistar rats, the body weight of which was between 230-250 grams at the beginning of the experiment. The animals were housed collectively in plastic cages in the vivarium of the Research Center for Biomedicine, Faculty of Medicine, University of Niš, in the conditions of controlled temperature and humidity, ventilation and artificially maintained 12-hour light and dark cycles. Food and water were available ad libitum during the experiment. The experiment was conducted in accordance to the Guide for the Care and Use of Laboratory Animals issued by the National Academy of Sciences, Washington, and Book of Regulations for Work with Experimental Animals adopted by the Faculty of Medicine, University of Niš. The experimental protocol was approved by the Ethics Committee of the Faculty of Medicine, University of Niš.

\section{Experimental procedure}

The animals were randomly divided into 4 groups ( $n=7-10), A, B, C$, and D. After a period of acclimatization that lasted for one week, impaired glucose tolerance was induced by an intraperitoneal injection of a freshly prepared solution of streptozotocin (STZ) in citrate buffer $(45 \mathrm{mg} / \mathrm{kg}$; Sigma, USA), given 15 minutes after intraperitoneal injections of nicotinamide $(110 \mathrm{mg} / \mathrm{kg}$; Sigma, USA) in the animals in groups C and D (14). The animals in groups $A$ and $B$ were injected with citrate buffer and saline respectively, according to the previously described procedure. After 4 weeks, when the experimental model was fully developed, the therapy with metformin $(100 \mathrm{mg} / \mathrm{kg}$; Merck Serono, France) was introduced in groups B and D.

The diagnosis of impaired glucose tolerance was established by glucose concentration measurement in venous blood. In order to confirm the 
presence of hyperglycemia, blood was collected from the tail vein, after 2 hours fast, 3 and 7 days after the induction of impaired glucose tolerance, using an automated blood glucose meter AccuChek Performa (Roche). The animals with glycemia between 8.3 and $12 \mathrm{mmol} / \mathrm{L}$ have successfully developed the model of impaired glucose tolerance, while others were removed from the experiment.

After 4 weeks, when the experimental model was established, in groups B and D metformin therapy was introduced $(100 \mathrm{mg} / \mathrm{kg}$; Merck Serono, France). Metformin was administered orally in drinking water. After two weeks of therapy with metformin, the animals were sacrificed by exsanguination after bilateral thoracotomy under deep anesthesia (Ketamidor, Richter Pharma AG; 100 $\mathrm{mg} / \mathrm{kg}$, ip). The blood was taken by cardiac puncture (terminal). Prior to sacrifice, blood glucose was measured under the same conditions as in the beginning of the experiment after 2 and 8 hours fast.

\section{Sample Preparation}

Serum and plasma were separated by centrifugation (15 minutes at $3000 \mathrm{~g}$ ) and stored at $20^{\circ} \mathrm{C}$. Na-EDTA was used as an anticoagulant.

Retinas were sampled by separation from the inner wall of the eyeball, after cutting the eyeball in the region of the cornea and removing the lens and vitreous body. The samples were weighed on an analytical scale and then homogenized in ice-cold, distilled water using a mini homogenizer (Homogenisator Mixy Mini cordless grinder, Nippon genetics). The prepared homogenates (10\%) were then centrifugated. The samples and homogenates were stored at $-80^{\circ} \mathrm{C}$, prior to biochemical analysis (determination of the MDA, AOPP, and protein content).

Determination of thiobarbituric acid reacting substances in retinal homogenates

The level of thiobarbituric acid reacting substances (TBARS) in the retina was determined using the spectrophotometric method by Andreeva et al. (1988) (15) The method is based on the reaction of thiobarbituric acid with MDA at a high temperature and in an acid environment. Color intensity of the chromogen (MDA-TBA2) formed in this reaction was read at $\lambda=532 \mathrm{~nm}$. TBARS concentration was calculated using a molar extinction coefficient equal to $1.54 \times 105 \mathrm{M}^{-1} \mathrm{~cm}^{-1}$ and was expressed in $\mathrm{mmol} / \mathrm{L}$ and then converted to $\mathrm{mg}$ of protein. Color intensity was determined on a plate reader. products

Determination of advanced oxidative protein

The level of advanced oxidative protein products (AOPP) was determined using the spectrophotometric method by Witko-Sarsat et al. (16).
Calibration was carried using chloramine-T solutions, which absorb light at $\lambda=340 \mathrm{~nm}$ in the presence of potassium iodide. AOPP concentration was expressed in micromol/L chloramine-T equivalents, and then converted to $\mathrm{mg}$ of protein.

\section{Determination of protein concentration}

Protein concentration in the retina homogenate was determined using the method described by Lauri (17). Bovine serum albumin was used as a standard.

\section{Statistical analysis}

Statistical analysis was performed using the IBM $^{\circledR}$ SPSS $^{\circledR}$ Statistics 21.0. The data were expressed as mean \pm standard deviation. The Kolmogorov-Smirnov test was used to test the normality of distribution. Comparison of continuous variables was performed using the single ANOVA test. The linear relationship between quantitative varia-bles was determined using the Pearson test for parametric data. The level of significance for all statistical tests was set at $5 \%$.

\section{Results}

Blood glucose concentration was significantly higher in animals with impaired glucose tolerance when compared to control group after 2 hours fast (C: $10.81 \pm 0.61 v s$. A: $6.53 \pm 0.75 \mathrm{mmol} / \mathrm{L}$; $\mathrm{p}<0.001$ ) and 8 hours ( $\mathrm{C}: 6.51 \pm 0: 34$ vs. . A: $4.82 \pm 0.19 \mathrm{mmol} / \mathrm{L} ; \mathrm{p}<0.001)$. Animals treated with metformin also had lower blood glucose values in comparison to untreated animals after 2 hours fast (D: $9.20 \pm 0.40 \mathrm{mmol} / \mathrm{L}$ vs. C, $p$ <0.001; B: $6: 54 \pm 0.68 \mathrm{mmol} / \mathrm{L}$ vs. NS) and 8 hours (D: $4.54 \pm 0.33 \mathrm{mmol} / \mathrm{L}$ vs. $\mathrm{C}: \mathrm{p}<0.001$; B: $4.03 \pm 0.21 \mathrm{mmol} / \mathrm{L}$ vs. $A, p<0.001$ ) (Figure 1).

As shown in Figure 2, the concentration of TBARS in the studied retinal homogenates was significantly higher in animals with impaired glucose tolerance when compared to controls ( $B$ : $4.09 \pm 0: 39$ vs. A: $2.98 \pm 0: 26 \mathrm{nmol} / \mathrm{mg}$ protein, $p<0.001)$. Animals treated with metformin did not show any decrease in TBARS concentration in their retinal homogenates compared to untreated ani-mals (A: $4.15 \pm 0.64 \mathrm{mmol} / \mathrm{mg}$ vs. C, NS; B: $2.82 \pm 0.21 \mathrm{mmol} / \mathrm{mg}$ vs. A; NS).

Compared to controls, the concentration of advanced oxidative protein products (Figure 3) was also significantly higher in animals with impaired glucose tolerance (B: $34.49 \pm 3.21$ vs. A: $26.26 \pm 3.16 \mathrm{nmol} / \mathrm{mg}$ protein, $\mathrm{p}<0.001)$. Animals treated with metformin had lower concentrations of AOPP in retinal homogenates compared to untreated animals, but no statistically significant differences were seen (D: $1.31 \pm 2.02 \mathrm{mmol} / \mathrm{mg}$ vs. C, NS; B: $23.95 \pm 2.09 \mathrm{mmol} / \mathrm{mg}$ vs. A; NS).

A strong positive correlation between serum glucose levels after 2 hours fast and TBARS con- 

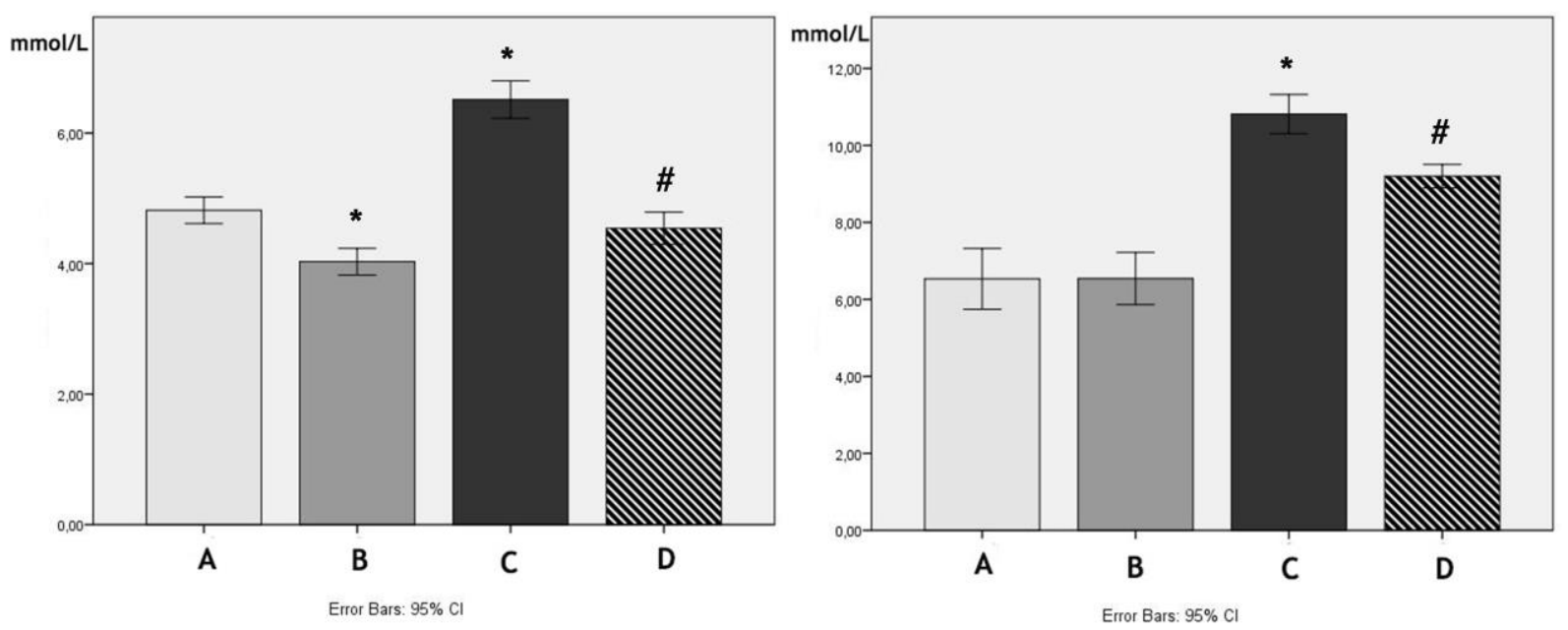

Figure 1. Glycemia after 2 hours fast (right) and after 8 hours fast (left) in animals with impaired glucose tolerance treated with metformin (A - control, B - control + metformin, C - impaired glucose tolerance, D - impaired glucose tolerance + metformin; $* p<$ 0.001 vs. control ; \#p $<0.001$ vs. impaired glucose tolerance ).

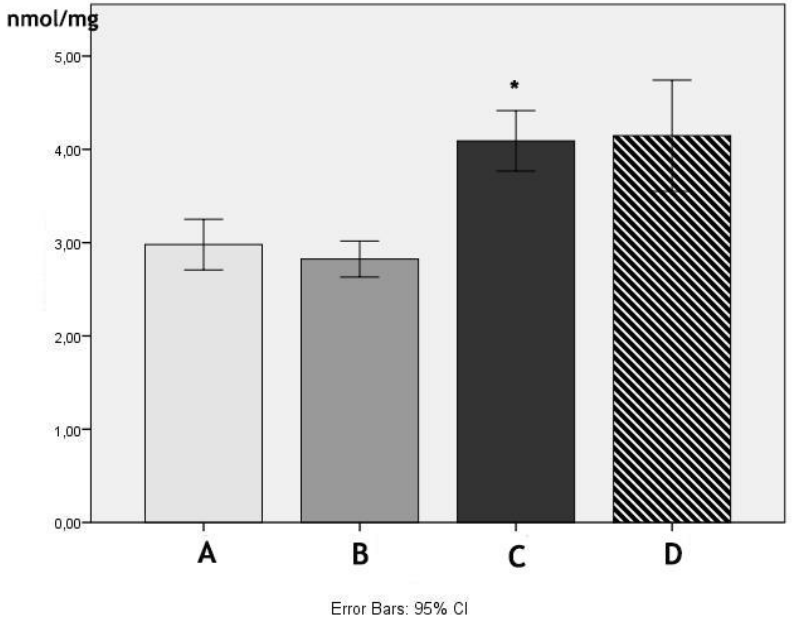

Figure 2. TBARS concentration in animals with impaired glucose tolerance treated with metformin (A - control, B control + metformin, $C$ - impaired glucose tolerance, $D$ impaired glucose tolerance + metformin; $* \mathrm{p}<0.001$ vs. controls)

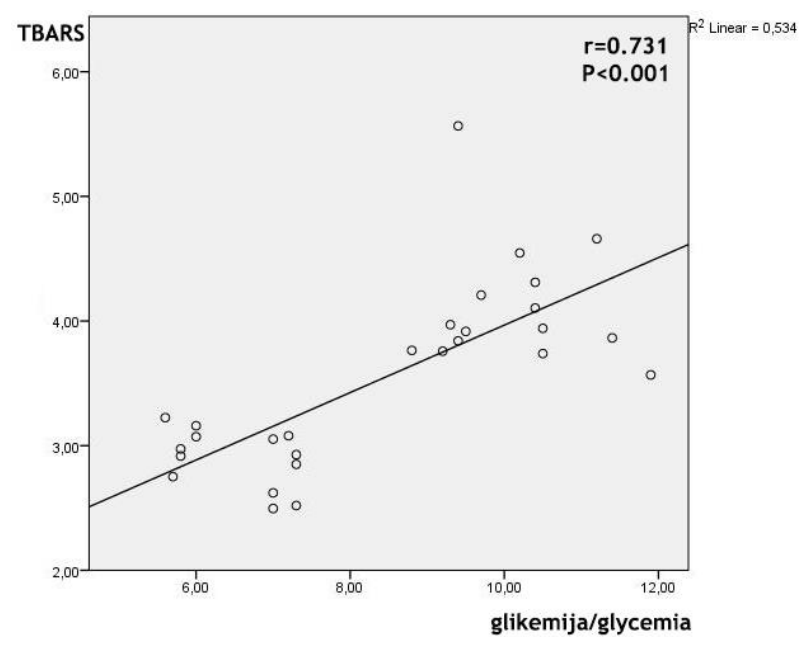

Figure 4. Correlation between glycemia after 2 hours fast and TBARS concentration in animals with impaired glucose tolerance treated with metformin

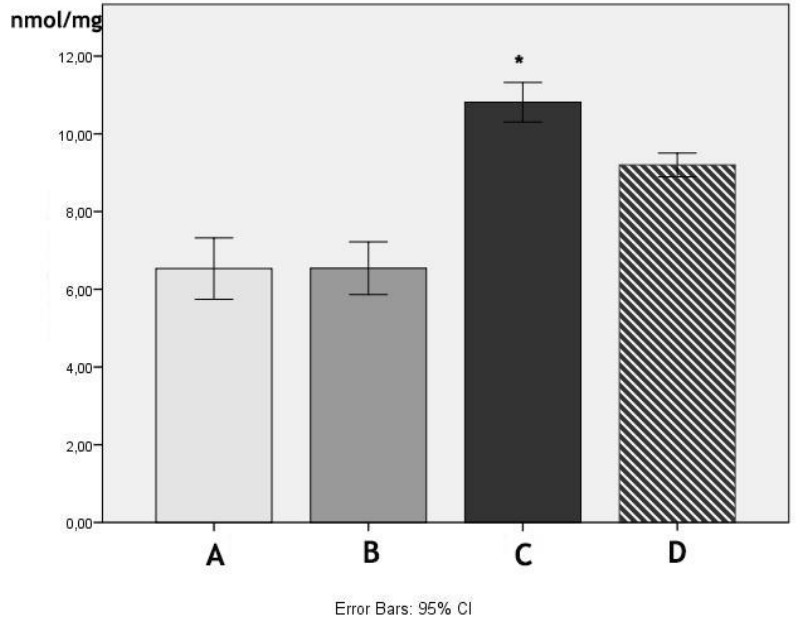

Figure 3. AOPP concentration in animals with impaired glucose tolerance treated with metformin (A - control, B - control + metformin, C - impaired glucose tolerance, D - impaired glucose tolerance + metformin; $* p<0.001$ vs. controls)

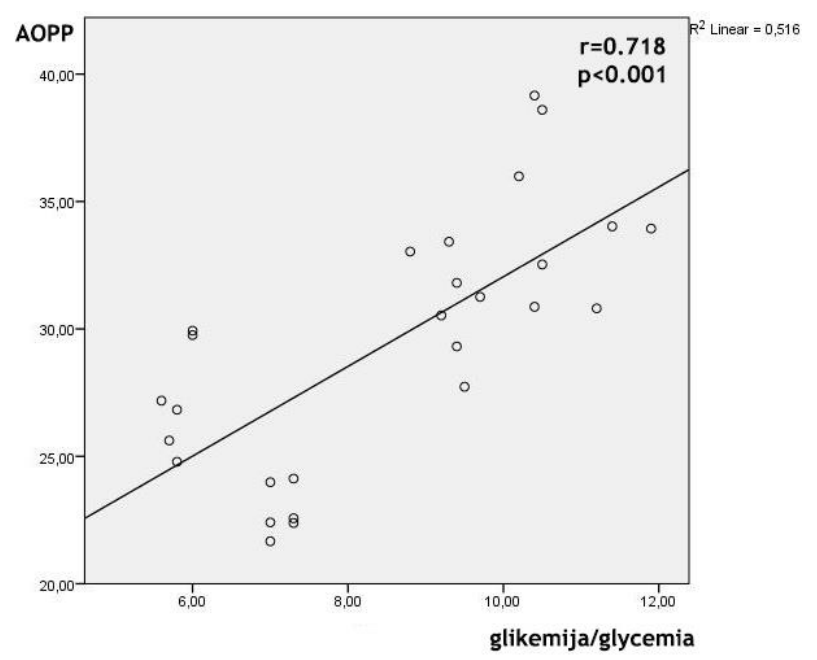

Figure 5. Correlation between glycemia after 2 hours fast and AOPP concentration in animals with impaired glucose tolerance treated with metformin. 
centration in the retina was found $(r=0.731, p<$ 0.001 ; Figure 4) and AOPP-a $(r=0.718, \mathrm{p}<$ 0.001 ; Figure 5).

\section{Discussion}

Oxidative stress plays an essential role in the occurrence of microvascular complications of diabetes (7), but there is little data on the intensity of oxidative stress in impaired glucose tolerance. Impaired glucose tolerance is characterized by postprandial hyperglycemia and large fluctuations in blood glucose which, according to the results of some studies, can lead to more significant microvascular and oxidative damage when compared to chronic hyperglycemia $(18,19)$.

The retina is particularly susceptible to oxidative damage due to a relatively high content of polyunsaturated fatty acids compared to other tissues, its high energy demands and exposure to UV radiation (8). However, there is little data about the degree of oxidative damage to the retinal tissue in impaired glucose tolerance. The fact that this disorder is sometimes diagnosed in people with newly diagnosed type 2 diabetes and people with impaired glucose tolerance (20) suggests that oxidative damage can develop early.

Our results suggest increased lipid peroxidation in the retina of rats with impaired glucose tolerance. TBARS concentration in the retinal tissue of rats with impaired glucose tolerance was significantly higher compared to that measured in control animals ( $p<0.001$ ), indicating a stronger lipid peroxidation. Yulek et al. (21) showed a significant increase $(p<0.001)$ in MDA concentration in the retina of diabetic rats treated with STZ (55 $\mathrm{mg} / \mathrm{kg}$ ). However, it should be mentioned that the animals in this experiment had significantly higher blood glucose values (cut-off $13.9 \mathrm{mmol} / \mathrm{L}$; diabetes $-24.97 \mathrm{mmol} / \mathrm{L}$ vs. control- 5:54 mmol/ L). Similar results related to the concentration of MDA in the retina of diabetic rats $(p<0.001)$ treated with STZ $(60 \mathrm{mg} / \mathrm{kg})$ were published by Shi et al. (22). Salido et al. (23) also showed elevated levels of TBARS in the retina of rats with mild diabetes that was characterized by postprandial hyperglycemia. This model is the most similar to our model, except for the fact that diabetes was induced by a low dose of STZ (25 mg/ $\mathrm{kg})$ in combination with daily oral administration of $30 \%$ sucrose solution, whereby the mean value of glycaemia in diabetic rats after 2 hours fast was significantly lower than that obtained in our study $(8.6 \mathrm{mmol} / \mathrm{L} \mathrm{vs}$. $10.81 \mathrm{mmol} / \mathrm{L})$. These data suggest that a significant increase in the intensity of lipid peroxidation in the retina already exists in impaired glucose tolerance and mild hyperglycemia, which indicates the importance of a timely screening and prevention of damage to the retina which may occur as a result of oxidative damage. Our results suggest that therapy with metformin $(100 \mathrm{mg} / \mathrm{kg})$ does not lead to a decrease in TBARS concentration in the retinal tissues compared to untreated animals. Pari and Ashokkummar (24) have previously reported that metformin $(500 \mathrm{mg} / \mathrm{kg}$ ) in combination with N-benzoyl-D-phenylala-nine - NBDP
(100 mg/kg), but not alone, leads to a reduction in the retinal TBARS concentration. The effect was explained by the effect of NBDP on the activity of cholinesterase in the retina. Therefore, it can be considered that metformin does not affect the process of lipid peroxidation in the retina. However, it must be taken into account that the concentration of TBARS in the blood of diabetic patients on metformin therapy are lower than the concentrations measured in patients without therapy (12) and that metformin in vitro treatment leads to reduced production of ROS in the cell culture of kidney mesangial cells (25), which indicates that it exerts a certain antioxidant effect.

The concentration of advanced oxidation protein products (AOPP), which indicates the degree of oxidative damage of proteins in the reactions with ROS, was as well significantly higher in the retina of animals with impaired glucose tolerance when compared to the control group ( $p$ $<0.001$ ). An increased concentration of AOPP was previously detected in the serum of patients suffering from diabetes $(26,27)$. Furthermore, it was also demonstrated that its serum concentration is higher in patients with poor glycemic control (26) and in those who developed some of the disease complications (27). Currently, there is no literature data available on the concentration of AOPP in the retina of rats with diabetes or impaired glucose tolerance. The data on oxidative damage to the retinal proteins are especially important due to the fact that a balanced metabolisam of structural and regulatory proteins is necessary for the normal functioning of this metabolically active tissue. Any disruption in protein metabolism can lead to subtle subclinical damage that can progress to the onset of the disease and vision loss (28). Our results indicate that metformin leads to a reduced concentration of AOPP in the retina, but not at a statistically significant level. In the literature, there are no data related to the effect of metformin on AOPP concentrations in the retina. However it was shown that this parameter is lower in the blood of patients with type 2 diabetes on metformin therapy than in the patients without treatment $(12,29)$.

The results of our study showed a strong positive correlation between the two oxidative damage parameters in the retina and blood glucose values. It is known that serum lipid hydroperoxide correlates with the prevalence of diabetic retinopathy (30). When it comes to AOPP, there are few data on the concentration of this parameter in patients with diabetic retinopathy and about the relationship of this parameter with the prevalence of the disease or glycemia. However, it was previously published that there was no correlation of serum AOPP and glycemia in patients with diabetes mellitus, although it was found that the values of AOPP in serum were increased (31).

Our results suggest a correlation between glycemia and oxidative damage in the retina which in fact is a confirmation of the importance of short-term postprandial hyperglycemia in oxidative damage to the retina. The values of both parameters of oxidative damage (MDA and AOPP) in 
animals with experimentally induced impaired glucose tolerance were elevated when compared to healthy animals, indicating that in this disorder this might lead to a strong oxidative stress in the retina, which is the first step in the development of diabetic retinopathy. Since the first disturbances in terms of oxidative damage to the retina occur when glucose tolerance is present (but not diabetes), an early diagnosis of this disorder and early therapeutic intervention would be advisable in order to prevent diabetic retinopathy. However, the therapy with metformin at a dose of $100 \mathrm{mg} / \mathrm{kg}$ showed no significant beneficial effect on the pro- cess of lipid peroxidation and oxidation of proteins in the retinal tissue of animals with impaired glucose tolerance. There is therefore a need for further investigation in order to detect an effective protector against oxidative damage in impaired glucose tolerance in order to prevent diabetic retinopathy.

\section{Acknowledgments}

This study is realized within the Project no. 43012 of the Ministry of Science, Education and Technical Development of the Republic of Serbia.

\section{References}

1. World Health Organization. Global Status Report On Noncommunicable Diseases 2014. Geneva; 2014. [PubMed]

2. Cade WT. Diabetes-related microvascular and macrovascular diseases in the physical therapy setting. Phys. Ther. (Internet). 2008 (cited 2015 Jan 16);88:1322-35. [PubMed]

3. World Health Organisation. Definition, diagnosis and classification of diabetes mellitus and its complications. Part 1: Diagnosis and classification of diabetes mellitus. Geneva; 1999. [PubMed]

4. Bertram MY, Vos T. Quantifying the duration of prediabetes. Aust. N. Z. J. Public Health (Internet). 2010 (cited 2015 Feb 25);34:311-4. [PubMed]

5. Tarr JM, Kaul K, Chopra M, Kohner EM CR. Pathophysiology of diabetic retinopathy. Diabet. Retin. Evidence-Based Manag. 2010;2013:1-30. [PubMed]

6. Kowluru $\mathrm{R}$ a, Chan P-S. Oxidative stress and diabetic retinopathy. Exp. Diabetes Res. 2007; 2007:43603. [PubMed]

7. Giacco F, Brownlee M. Oxidative stress and diabetic complications. Circ. Res. 2010;107:1058-70. [PubMed]

8. Kumari S, Panda S, Mangaraj M, Mandal MK, Mahapatra PC. Plasma MDA and antioxidant vitamins in diabetic retinopathy. Indian J. Clin. Biochem. 2008 (cited 2015 Feb 25);23:158-62. [PubMed]

9. Susinjan Bhattacharya. Reactive Oxygen Species and Cellular Defense System. Rani V, Yadav UCS, editors. Free Radicals Hum. Heal. Dis. New Delhi: Springer India; 2015.

10. Al-Shabrawey M, Smith S. Prediction of diabetic retinopathy: Role of oxidative stress and relevance of apoptotic biomarkers. EPMA J. 2010;1:56-72. [CrossRef] [PubMed]

11. Mandal N, Lewis GP, Fisher SK, Heegaard S, Prause $\mathrm{JU}$, la Cour $M$, et al. Protein changes in the retina following experimental retinal detachment in rabbits. Mol. Vis. 2011;17:2634-48. [PubMed]
12. Chakraborty A, Chowdhury S, Bhattacharyya M. Effect of metformin on oxidative stress, nitrosative stress and inflammatory biomarkers in type 2 diabetes patients. Diabetes Res. Clin. Pract. 2011; 93(1):56-62. [PubMed]

13. Alhaider AA, Korashy HM, Sayed-Ahmed MM, Mobark $M$, Kfoury $H$, Mansour MA. Metformin attenuates streptozotocin-induced diabetic nephropathy in rats through modulation of oxidative stress genes expression. Chem. Biol. Interact. $2011 ; 192: 233-42$. [CrossRef] [PubMed]

14. Masiello P, Broca C, Gross R, Roye M, Manteghetti $M$, Hillaire-Buys $D$, et al. Experimental NIDDM: development of a new model in adult rats administered streptozotocin and nicotinamide. Diabetes. 1998 ;47:224-9. [CrossRef] [PubMed]

15. Andreeva IL, Kožemjakin AL KA. (Modification of the method of measurement of lipid peroxides in test with thiobarbituric acid). Lab. Delo . 1988 ;413.

16. Witko-Sarsat $V$, Friedlander $M$, Capeillère-Blandin C, Nguyen-Khoa T, Nguyen AT, Zingraff J, et al. Advanced oxidation protein products as a novel marker of oxidative stress in uremia. Kidney Int. . $1996 ; 49: 1304-13$. [PubMed]

17. Lowry OH, Rosebrough NJ, FarrAL, Randall RJ. Protein measurement with the Folin phenol reagent. J. Biol. Chem . $1951 ; 193: 265-75$. [PubMed]

18. 18. Ceriello A, Esposito K, Piconi L, Innat M a., Thorpe JE, Testa $\mathrm{R}$, et al. Oscillating glucose is more deleterious to endothelial function and oxidative stress than mean glucose in normal and type 2 diabetic patients. Diabetes. 2008;57:134954. [CrossRef] [PubMed]

19. Monnier L. Activation of Oxidative Stress by in Patients With Type 2 Diabetes. 2006;295:1681-7. [PubMed]

20. Diabetes Prevention Program Research Group. The prevalence of retinopathy in impaired glucose tolerance and recent-onset diabetes in the Diabetes Prevention Program. Diabet. Med. 2007 ;24:13744. [PubMed] 
21. Yülek F, Or M, Özoğul C, Isik AC, Ari N, Stefek M, et al. Effects of Stobadine and Vitamin $E$ in DiabetesInduced Retinal Abnormalities: Involvement of Oxidative Stress. Arch. Med. Res. 2007;38:503-11. [PubMed]

22. Shi X, Liao S, Mi H, Guo C, Qi D, Li F, et al. Hesperidin prevents retinal and plasma abnormalities in streptozotocin-induced diabetic rats. Molecules. 2012;17:12868-81. [CrossRef] [PubMed]

23. Salido EM, de Zavalía N, Schreier L, De Laurentiis A, Rettori V, Chianelli $M$, et al. Retinal changes in an experimental model of early type 2 diabetes in rats characterized by non-fasting hyperglycemia. Exp. Neurol. Elsevier Inc.; 2012;236:151-60. [PubMed]

24. Pari L, Ashokkumar N. Effect of N-benzoyl-Dphenylalanine, a new potential oral antidiabetic agent, in neonatal streptozotocin-induced diabetes in rats. Pharmacol. Rep.2005;57:498-503. [PubMed]

25. Yao X-M, Ye S-D, Xiao C-C, Gu J-F, Yang D, Wang S. Metformin alleviates high glucose-mediated oxidative stress in rat glomerular mesangial cells by modulation of p38 mitogen-activated protein kinase expression in vitro. Mol. Med. Rep. $2015 ; 12(1)$ : 520-6. [PubMed]

26. Cakatay U. Protein oxidation parameters in type 2 diabetic patients with good and poor glycaemic control. Diabetes Metab. 2005;31:551-7. [CrossRef] [PubMed]

27. Martín-Gallán $P$, Carrascosa A, Gussinyé $M$, Domínguez C. Biomarkers of diabetes-associated oxidative stress and antioxidant status in young diabetic patients with or without subclinical complications. Free Radic. Biol. Med. 2003;34: 1563-74. [PubMed]

28. Tzekov R, Stein L, Kaushal S. Protein Misfolding and Retinal Degeneration. Cold Spring Harb. Perspect. Biol. 2011;3:a007492-a007492. [PubMed]

29. Esteghamati A, Eskandari D, Mirmiranpour $H$, Noshad S, Mousavizadeh $M$, Hedayati $M$, et al. Effects of metformin on markers of oxidative stress and antioxidant reserve in patients with newly diagnosed type 2 diabetes: a randomized clinical trial. Clin. Nutr. 2013;32:179-85. [PubMed]

30. Armstrong D, Abdella N, Salman A, Miller N, Rahman EA, Bojancyzk M. Relationship of lipid peroxides to diabetic complications. Comparison with conventional laboratory tests. J. Diabetes Complications.1992;6:116-22. [CrossRef] [PubMed]

31. Kalousová M, Skrha J, Zima T. Advanced glycation end-products and advanced oxidation protein products in patients with diabetes mellitus. Physiol. Res. 2002;51:597-604. [PubMed] 


\title{
UTICAJ TERAPIJE METFORMINOM NA PARAMETRE OKSIDATIVNOG OŠTEĆENJA U RETINI PACOVA SA POREMEĆENOM TOLERANCIJOM GLUKOZE
}

\author{
Branka Đorđevići ${ }^{1}$ Dušan Sokolović ${ }^{1}$, Tatjana Cvetković ${ }^{1}$, \\ Tatjana Jevtović-Stoimenov ${ }^{1}$, Milena Despotović ${ }^{1}$, \\ Andrej Veljković ${ }^{1}$, Jelena Bašićc ${ }^{1}$, Davor Đukić ${ }^{1}$, Nataša Stević ${ }^{1}$, \\ Aleksandra Veličkov'², Jelena Milenkovićs, Sanja Milošević ${ }^{4}$
}

\author{
${ }^{1}$ Univerzitet u Nišu, Medicinski fakultet, Katedra za biohemiju, Niš, Srbija \\ ${ }^{2}$ Univerzitet u Nišu, Medicinski fakultet, Katedra za histologiju i embriologiju, Niš, Srbija \\ 3Univerzitet u Nišu, Medicinski fakultet, Katedra za patološku fiziologiju, Niš, Srbija \\ ${ }^{4}$ Univerzitet u Nišu, Medicinski fakultet, Niš, Srbija \\ Kontakt: Branka Đorđević \\ Bul. dr Zorana Đinđića 81, 18000 Niš, Srbija \\ E-mail: brankadjordjevic83@gmail.com
}

Poremećena tolerancija glukoze je poremećaj koji se karakteriše povišenim vrednostima glikemije, ali ipak nedovoljno visokim da bi se postavila dijagnoza šećerne bolesti. Dijabetesna retinopatija je jedna od komlikacija šećerne bolesti za čiju je patogenezu značajan oksidativni stres. Metformin je trenutno lek prvog izbora u terapiji dijabetesa melitusa tip 2.

Cilj rada bio je da na animalnom modelu utvrdimo da li postoji oksidativno oštećenje retine u poremećenoj toleranciji glukoze (analizom tiobarbiturat-reagujućih supstanci - TBARS - i uznapredovalih produkata oksidacije proteina - AOPP) i da li to oštećenje može biti ublaženo primenom metformina.

Eksperiment je izveden na 10 nedelja starim Wistar pacovima, koji su nasumično podeljeni u četiri grupe. Poremećena tolerancija glukoze izazvana je pomoću intraperitonealne injekcije rastvora streptozotocina (STZ), koja je data 15 minuta nakon intraperitonealne injekcije nikotinamida. Nakon četiri nedelje, uvedena je terapija metforminom (100 mg/kg, per os). Nakon dve nedelje, životinje su žrtvovane u dubokoj anesteziji.

Koncentracije TBARS i AOPP u homogenatu retine bile su značajno više kod životinja sa poremećenom tolerancijom glukoze u poređenju sa kontrolom (za TBARS: $4,09 \pm 0,39$ vs. $2,98 \pm 0,26 ; p<0,001$ i za AOPP: $34,49 \pm 3,21$ vs. $26,26 \pm 3,16 ; p$ $<0,001)$. Utvrđeno je i postojanje jake pozitivne korelacije između vrednosti glikemije i nivoa TBARS ( $r=0,757, p<0,01$ (grafikon 4) i nivoa AOPP $(r=0,683, p<0,01) u$ retini. Metformin nije pokazao značajne efekte na koncentracije ispitivanih parametara.

Vrednosti ispitivanih parametara oksidativnog oštećenja kod životinja sa poremećenom tolerancijom glukoze ukazuju na postojanje intenzivnijeg oksidativnog stresa u retini, što predstavlja prvi korak u nastanku dijabetesne retinopatije. Terapija metforminom u dozi od $100 \mathrm{mg} / \mathrm{kg}$ nije pokazala značajne korisne efekte na proces lipidne peroksidacije i oksidaciju proteina u tkivu retine kod životinja sa poremećenom tolerancijom glukoze.

Acta Medica Medianae 2017;56(4):75-82. glukoze

Ključne reči: dijabetesna retinopatija, oksidativni stres, poremećena tolerancija 